\title{
Prediktor perundungan siswa sekolah dasar
}

\author{
Ihsana Sabriani Borualogo', Hedi Wahyudi', Sulisworo Kusdiyati ${ }^{3}$ \\ 1,2,3Fakultas Psikologi Universitas Islam Bandung, Indonesia
}

\begin{tabular}{l}
\hline Info Artikel \\
\hline Sejarah Artikel: \\
Diterima \\
I 9 September 2019 \\
Direview \\
02 Oktober 2019 \\
Disetujui \\
08 Oktober 2019 \\
Dipublikasikan \\
27 Februari 2020 \\
\hline Keywords: \\
aggressive behavior, \\
elementary school, \\
parent's child rearing, \\
predictors of bullying
\end{tabular}

\begin{abstract}
Abstrak
Objektif: perundungan merupakan persoalan serius yang memberikan dampak negatif bagi anak. Tujuan penelitian ini untuk mengeksplorasi prediktor perundungan siswa sekolah dasar di Kota Bandung. Hal ini penting agar dapat diketahui faktor-faktor yang berkontribusi dan meningkatkan peluang terjadinya perundungan pada siswa sekolah dasar. Dengan mengetahui prediktor tersebut, maka dapat dilakukan upaya pencegahan terjadinya perundungan.
\end{abstract}

Metode: sampel penelitian ini adalah 809 siswa sekolah dasar di Kota Bandung yang dipilih melalui stratified cluster random sampling dari II sekolah dasar. Terdapat $47.6 \%$ responden perempuan dan $52.4 \%$ responden lakilaki. Data dianalisis menggunakan regresi logistik binari.

Temuan: hasil penelitian menunjukkan bahwa keyakinan personal yang mendukung tindak kekerasan merupakan prediktor perundungan fisik, verbal, dan psikologis.

Kesimpulan: pola asuh ayah yang menolak anak merupakan prediktor perundungan fisik, dan pola asuh ibu yang menolak anak merupakan predictor perundungan psikologis. Ketidakhadiran ayah memberikan kontribusi hampir 2 kali lebih besar dalam meningkatkan peluang anak menjadi korban perundungan.

\section{The predictor of bullying in elementary students \\ Objectives: bullying is a serious problem which affected children negatively. The aim of this study was to explore predictor of bullying in elementary students in Kota Bandung. This is very crucial to know factors which contribute bullying cases in elementary students. By knowing predictors of bullying, we will be able to prevent bullying cases rising in children.}

Method: samples were 809 elementary students in Kota Bandung which chosen by stratified cluster random sampling from II elementary schools. There were $47.6 \%$ girls and $52.4 \%$ boys

Findings: personal belief which support aggression was a predictor of physical, verbal, and psychological bullying.

Conclusions: Father who rejected children was a predictor of physical bullying, while mother who rejected children was a predictor of psychological bullying. Unavailability of the father contributed twice bigger in the probability of the children being bullied.

\footnotetext{
*Alamat korespondensi:

Fakultas Psikologi Universitas Islam Bandung, Jl. Taman Sari No, I, Taman Sari, Kota Bandung ihsana.sabriani@yahoo.com; hediway@yahoo.co.id; sulisworo.kusdiyati@gmail.com
} 


\section{Pendahuluan}

Kata perundungan mungkin belum terlalu familiar bagi masyarakat Indonesia, tetapi kasus perundungan banyak terjadi di Indonesia. Perundungan adalah terjemahan dari kata bullying dalam Bahasa Inggris. Perundungan didefinisikan sebagai perilaku agresif yang ditujukan untuk menyakiti, dilakukan oleh seseorang atau sekelompok orang terhadap orang lain karena adanya ketidakseimbangan kekuatan, serta dilakukan berulang kali atau berpeluang dilakukan secara berulang kali (Espelage \& Hong, 2018; Espelage \& Swearer, 2003; Olweus, 1978).

Perundungan merupakan permasalahan serius yang dihadapi anak-anak di dunia, di mana angka prevalensi kejadiannya tergolong tinggi. Hasil penelitian Wang, lanotti, dan Nansel (2009) di Amerika Serikat terhadap 7,182 siswa kelas 6 hingga kelas 10 menunjukkan bahwa 20.8\% mengalami perundungan fisik (dipukul), 53.6\% mengalami perundungan verbal (diejek), dan $5 \mathrm{I} .4 \%$ mengalami perundungan psikologis (dikucilkan). Data dari National Center for Education Statistics di Amerika Serikat menunjukkan bahwa 13\% siswa usia 12-18 tahun mengalami perundungan verbal dengan diejek dan dipanggil dengan julukan buruk, $5 \%$ mengalami perundungan fisik dengan didorong maupun dipukul, dan $5 \%$ mengalami perundungan psikologis dengan dikucilkan dari berbagai kegiatan (Musu-Gillette, Zhang, Wang, Zhang, Kemp, Diliberti, \& Oudekerk, 2018). Hasil Global School-based Student Health Survey and Health Behaviour in School-aged Children tahun 2018 di I 44 negara menunjukkan bahwa $16.1 \%$ anak pernah mengalami perundungan fisik (en.unesco.org). Beberapa kasus perundungan bahkan menjadi perhatian media internasional karena korban perundungan mengalami tekanan psikologis yang sangat serius dan memutuskan untuk bunuh diri, misalnya kasus Amanda Todd, seorang remaja putri asal British Columbia, Canada berusia 15 tahun. Bahkan Presiden Amerika Serikat Barack Obama pada kegiatan The White House Conference of Bullying Prevention di tahun $201 \mathrm{I}$ menekankan betapa pentingnya menghentikan perundungan karena efek buruk yang ditimbulkan oleh perundungan terhadap perkembangan anak, serta mengajak seluruh orang tua, guru, dan lapisan masyarakat untuk menciptakan iklim sekolah di mana anak merasa aman dan merasa menjadi bagian dari sekolah (www.nbenews.com).

Perundungan juga merupakan permasalahan serius bagi anak-anak Indonesia. Hasil survey internasional yang dilakukan oleh Trends in Mathematics and Science Study (TIMSS) pada tahun $201 \mathrm{I}$ yang melibatkan 46 negara menunjukkan bahwa $55 \%$ anak Indonesia berusia II sampai I5 tahun pernah menjadi korban perundungan di sekolah (United Nations, 2016). Data ini sejalan dengan hasil survey Children's Worlds di Indonesia yang menunjukkan bahwa angka kejadian perundungan terhadap siswa sekolah dasar di $27 \mathrm{Kota} /$ Kabupaten di Jawa Barat tergolong tinggi (Borualogo \& Gumilang, 2019). Sebanyak 52.5\% siswa sekolah dasar mengalami perundungan fisik dengan dipukul oleh anak lain di sekolah setidaknya satu kali dalam satu bulan terakhir; sebanyak $60.6 \%$ siswa sekolah dasar mengalami perundungan verbal dengan diejek atau dipanggil dengan julukan buruk oleh anak lain di sekolah setidaknya satu kali dalam satu bulan terakhir; dan sebanyak $49.6 \%$ siswa sekolah dasar mengalami perundungan psikologis dengan dikucilkan oleh anak lain di kelas setidaknya satu kali dalam satu bulan terakhir (Borualogo \& Gumilang, 2019).

Dari data Children's Worlds Survey di Indonesia tersebut, Kota Bandung memiliki angka kejadian perundungan yang tergolong tinggi. Sebanyak $48.9 \%$ siswa SD di Kota Bandung pernah dipukul oleh anak lain di sekolah setidaknya satu kali dalam satu bulan terakhir, 61.4\% siswa SD di Kota Bandung pernah dipanggil dengan nama yang buruk oleh siswa lain di sekolah setidaknya satu kali dalam satu bulan terakhir, dan sebanyak 47\% siswa SD di Kota Bandung pernah dikucilkan oleh siswa lain di kelas setidaknya satu kali dalam satu bulan terakhir (Borualogo \& Gumilang, 2019).

Hasil-hasil penelitian internasional mengungkapkan bahwa perundungan memberikan dampak negatif terhadap kesehatan mental dan kesejahteraan anak (Borualogo \& Casas, 2019b), mengakibatkan kerusakan jangka panjang pada kemampuan akademik, psikososial, dan kesehatan mental (Cook, Williams, Guerra, Kim, \& Sadek, 20I0; Copeland, Wolke, Angold, \& Costello, 2013; Espelage, Low, \& De La Rue, 2012). Menjadi korban perundungan mempengaruhi rasa keberhargaan diri anak dan memberikan dampak serius bagi perkembangan mereka (Dombrowski \& Gischlar, 2006), meningkatkan masalah tingkah laku dan menurunkan perilaku prososial (Wolke, Woods, Bloomfield, \& Karstadt, 2000). Penelitian di Indonesia menunjukkan bahwa anak-anak yang 
menjadi korban perundungan memiliki kondisi well-being yang lebih rendah dibandingkan anak-anak yang tidak menjadi korban perundungan (Borualogo \& Casas, 2019b).

Studi yang dilakukan oleh Copeland et al. (2013) menunjukkan bahwa anak yang menjadi korban perundungan didiagnosis memiliki resiko yang lebih tinggi mengalami depresi dan bunuh diri dibandingkan yang tidak pernah menjadi korban perundungan. Hasil studi tersebut sejalan dengan studi yang dilakukan di Korea oleh Kim, Koh, dan Leventhal (2005). Bahkan studi yang dilakukan oleh Kim dan Leventhal (2008) menunjukkan terjadinya peningkatan angka peluang dari 1.40 menjadi 10.00 yang mengacu pada peluang ide melakukan bunuh diri hingga perilaku bunuh diri.

Individu yang pada masa anak-anak yang menjadi korban perundungan dilaporkan mengalami gangguan kecemasan, psikosomatis, dan gangguan depresi ketika dewasa (Ttofi, Farrington, Losel, \& Loeber, 20II). Sedangkan studi yang dilakukan oleh Kaminski dan Fang (2009) menunjukkan bahwa remaja yang pada masa anak-anak menjadi korban perundungan memiliki 2.4 kali lebih besar peluang memiliki ide bunuh diri dan 3.3 kali lebih besar peluang melakukan upaya bunuh diri dibandingkan yang tidak pernah menjadi korban perundungan

Mengingat dampak negatif yang sangat serius yang ditimbulkan akibat menjadi korban perundungan, maka sangatlah krusial untuk melakukan upaya-upaya menghentikan terjadinya perundungan. Untuk dapat menghentikan terjadinya perundungan, tentu dibutuhkan pengetahuan mengenai faktorfaktor yang menjadi prediktor perundungan. Untuk itu, penelitian ini dilakukan guna mengetahui faktor-faktor yang menjadi prediktor perundungan siswa SD di Kota Bandung. Hal ini menjadi sangat penting, mengingat kasus-kasus perundungan sangat sering terjadi di Kota Bandung dan memberikan dampak negatif bagi perkembangan anak. Bahkan beberapa kasus perundungan di Kota Bandung sempat viral di media sosial dan menjadi perhatian publik (Ispranoto, 2018; Yulius, 2018).

Untuk mengkaji prediktor perundungan siswa SD di Kota Bandung ini, peneliti menggunakan teori sosial-ekologi dari Bronfenbrenner (1979). Bronfenbrenner (1979) menjelaskan bahwa individu berinteraksi dengan konteks lingkungannya yang dijelaskan dalam berbagai lapisan sistem. Interaksi yang dilakukan individu dengan konteks lingkungannya pada tiap lapisan sistem ini memengaruhi berbagai aspek perkembangan psikologis individu.

Lapisan sistem pertama disebut sebagai microsystem, di mana individu memiliki kontak langsung dengan orang-orang terdekatnya dalam relasi tatap muka, seperti orang tua, saudara kandung, teman sekolah, dan guru. Interaksi antar komponen di dalam microsystem berada dalam lapisan sistem yang lebih luas, yaitu mesosystem.

Pada mesosystem, terjadi interaksi antara konteks rumah (keluarga) dan konteks sekolah yang melibatkan orang tua dalam aktivitas sekolah anak. Konteks sosial berikutnya adalah exosystem, di mana anak tidak memiliki kontak langsung, tetapi memengaruhi anak secara tidak langsung melalui microsystem-nya, misalnya persepsi guru atas iklim sekolah, upaya-upaya yang dilakukan oleh sekolah untuk mengatasi perundungan, serta kebijakan yang dikeluarkan oleh sekolah untuk mencegah peningkatan angka kejadian perundungan.

Sedangkan lapisan berikutnya adalah macrosystem yang mengacu pada cetak biru budaya yang menentukan struktur sosial dan aktivitas pada berbagai tingkatan, misalnya sampai sejauh mana suatu kelompok masyarakat tidak mengijinkan terjadinya perundungan dan nilai-nilai budaya yang berlaku dalam masyarakat tersebut terkait penolakan atas perundungan.

Dan lapisan terakhir adalah chronosystem yang menyertakan konsistensi atau perubahan dari individu dan lingkungannya sepanjang rentang kehidupan (Bronfenbrenner, 1979).

Melalui pendekatan teori sosial-ekologi dari Bronfenbrenner ini, maka akan dikaji faktor-faktor yang diduga terkait perundungan untuk dapat menentukan prediktor perundungan pada siswa SD di Kota Bandung. Dengan mengetahui prediktor perundungan pada siswa SD, diharapkan dapat memberikan informasi mengenai faktor-faktor yang dapat diupayakan untuk mengurangi angka kejadian perundungan. 


\section{Metode}

Untuk mendapatkan sampel yang representatif, peneliti menyusun kerangka sampling berupa daftar sekolah di Kota Bandung dengan menggunakan teknik sampling acak klaster berstratifikasi (stratified cluster random sampling). Stratifikasi disusun berdasarkan ranking sekolah yang diperoleh dari nilai akreditasi sekolah. Klaster disusun berdasarkan tipe sekolah, yaitu sekolah negeri dan sekolah swasta, serta sekolah berbasis agama dan sekolah tidak berbasis agama. Berdasarkan kerangka sampling tersebut, kemudian terpilih secara acak II sekolah dasar di Kota Bandung. Adapun karakteristik sampel adalah siswa sekolah dasar kelas 4, 5, dan 6 berusia $10-14$ tahun di Kota Bandung. Rincian karakteristik sampel disajikan pada Tabel I.

Tabel I. Karakteristik sampel

\begin{tabular}{lccc}
\cline { 2 - 4 } & Perempuan & Laki-laki & Total \\
\hline I tahun & 171 & 167 & 338 \\
II tahun & 131 & 140 & 271 \\
I 2 tahun & 73 & 92 & 165 \\
I3 tahun & 10 & 23 & 33 \\
I tahun & 0 & 2 & 2 \\
Total & 385 & 424 & 809 \\
\hline
\end{tabular}

Sampel penelitian ini adalah siswa dari II SD di Kota Bandung yang duduk di kelas 4, 5 dan 6 sekolah dasar berusia antara 10 hingga 14 tahun, siswa perempuan berjumlah 385 (47.6\%) dan siswa laki-laki berjumlah 424 (52.4\%).

Sebelum melakukan pengambilan data, peneliti mengajukan permohonan kepada Komite Etik FK UNPAD (http://kepk.fk.unpad.ac.id) untuk mendapatkan persetujuan melakukan penelitian. Peneliti juga mengirimkan Persetujuan Setelah Penjelasan (PSP) atau inform consent kepada orang tua siswa melalui guru untuk mendapatkan ijin dari orang tua siswa terkait keikutsertaan anaknya dalam penelitian ini. Anak juga dimintai kesediaannya dan diberikan informasi bahwa data mereka akan dijaga kerahasiaannya, dan mereka bebas untuk menjawab atau tidak menjawab pertanyaan yang diajukan dalam kuesioner. Peneliti juga mendapatkan ijin untuk melakukan penelitian yang diperoleh dari Kesbangpol Kota Bandung dan Dinas Pendidikan dan Kebudayaan Kota Bandung.

Sebelum mengisi kuesioner, siswa menjawab contoh pertanyaan dalam lembar latihan sehingga dapat memahami cara menjawab daftar pertanyaan dalam kuesioner. Pengambilan data dilakukan secara klasikal di dalam kelas dan siswa mengisi sendiri kuesionernya. Dua orang enumerator yang terlatih hadir di dalam kelas untuk menjamin terlaksananya pengambilan data dengan baik dan menjawab pertanyaan-pertanyaan dari siswa.

Terdapat tiga variabel terikat mengenai perundungan di sekolah, yaitu perundungan fisik, perundungan verbal, dan perundungan psikologis. Ketiga variabel perundungan tersebut diukur melalui indikator perundungan yang berasal dari proyek penelitian Children's Worlds (www.isciweb.org) yang telah diterjemahkan ke dalam Bahasa Indonesia (Borualogo \& Casas, 2019a; Borualogo, Gumilang, Mubarak, Khasanah, Wardati, Diantina, Permataputri, Casas, 2018).

Perundungan di sekolah diukur melalui frekuensi mengalami perundungan fisik ("Selama satu bulan terakhir, seberapa sering kamu mengalami dipukul oleh anak-anak lain di sekolahmu - tidak termasuk ketika berkelahi atau bermain pukul-pukulan), frekuensi mengalami perundungan verbal ("Selama satu bulan terakhir, seberapa sering kamu mengalami dipanggil/dijuluki dengan nama yang buruk oleh anak-anak lain di sekolahmu"), dan perundungan psikologis ("Selama satu bulan terakhir, seberapa sering kamu mengalami dimusuhi/dikucilkan oleh anak-anak lain di kelasmu") (Borualogo \& Gumilang, 2019). Pertanyaan-pertanyaan ini memiliki 4 skala frekuensi sebagai pilihan jawabannya, yaitu 0 = tidak pernah, $I=$ satu kali, 2 = dua atau tiga kali, 3 = lebih dari tiga kali. Untuk menganalisis prediktor ketiga variabel perundungan ini, maka setiap skor dari indikator 
perundungan ditransformasikan menjadi variabel dikotomus, di mana $I$ = tidak pernah mengalami perundungan selama satu bulan terakhir, dan 2 = pernah mengalami perundungan dalam satu bulan terakhir.

Terdapat lima kelompok variabel yang akan dianalisis sebagai variabel bebas yang akan mewakili beberapa konteks dalam kehidupan anak pada microsystem dan mesosystem sesuai acuan teori sosial-ekologi yang digunakan dalam penelitian ini (Bronfenbrenner, 1979). Kelima kelompok variabel tersebut adalah variabel demografik, variabel kebahagiaan/kesejahteraan anak di sekolah, variabel relasi dengan teman dan anak lain di sekolah, variabel rasa aman dan frekuensi kekerasan di sekolah, variabel iklim sekolah, variabel pola asuh orang tua, dan variabel keyakinan personal yang mendukung tindak kekerasan.

Variabel demografik yang dianalisis adalah usia, jenis kelamin, dan kondisi ayah/ibu yang tidak tinggal dengan anak karena bekerja di luar kota/luar negeri. Variabel kebahagiaan/kesejahteraan anak di sekolah diukur melalui CW-DBSWBS (Children's Worlds-Domain Based Subjective Well-Being Scale) dari Children's Worlds (www.isciweb.org). Demikian pula dengan variabel relasi dengan teman dan anak lain di sekolah, serta variabel rasa aman dan frekuensi kekerasan di sekolah diukur melalui kuesioner dari Children's Worlds. Variabel iklim sekolah diukur melalui alat ukur iklim sekolah dari Cornell (2016). Variabel pola asuh orang tua diukur menggunakan EMBU-C (Muris, Meesters, \& van Brakel, 2003). Variabel personal mengukur keyakinan yang mendukung kekerasan berasal dari Beliefs Supportive of Violence Scale dari Espelage, Bosworth, dan Simon (2000). Seluruh alat ukur telah diadaptasi ke dalam Bahasa Indonesia dengan mengikuti pedoman standar penerjemahan dan adaptasi kultural alat ukur dari van de Vijver dan Hambleton (1996), van de Vijver dan Poortinga (2005), dan van de Vijver (2015).

Sebelum melakukan analisis, terlebih dahulu data dibersihkan. Proses pembersihan dilakukan dengan menghapus data siswa yang tidak memberikan keterangan mengenai apakah mereka korban perundungan ataukah bukan. Terdapat 5 orang siswa yang dihapus dari data, sehingga dari 814 siswa yang berpartisipasi, hanya 809 siswa yang akan diolah datanya.

Data penelitian dianalisis menggunakan regresi logistik binari. Regresi logistik binari digunakan karena variabel terikat pada penelitian ini merupakan variabel dikotomus. Masing-masing indikator perundungan dianalisis sebagai variabel terikat. Untuk dapat menentukan variabel bebas yang akan diujikan menggunakan regresi logistik binari, maka keseluruhan variabel bebas diuji korelasinya dengan masing-masing variabel terikat dengan menggunakan Chi-square. Hanya variabel-variabel yang memiliki korelasi yang signifikan dengan variabel terikat yang kemudian dianalisis menggunakan regresi logistik binari. Hasil uji korelasi Chi-square disajikan dalam tabel 2. 


\section{Hasil}

Hasil pengujian Chi-square disajikan pada tabel 2, dilanjutkan dengan pemaparan hasil pengujian regresi logistik binari.

\section{Tabel 2.}

Hasil analisis Chi-square prediktor perundungan dengan perundungan fisik, perundungan verbal, dan perundungan psikologis

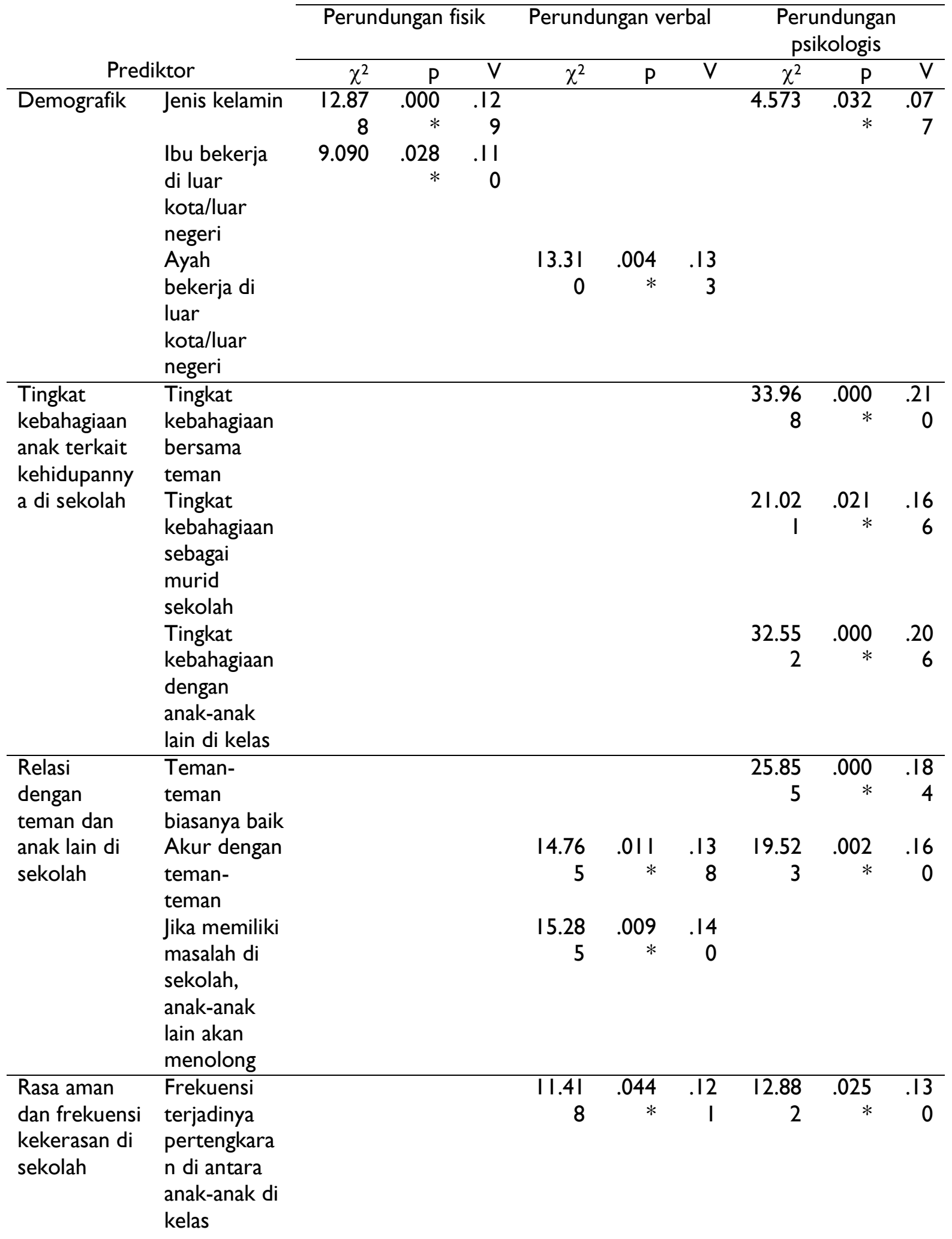




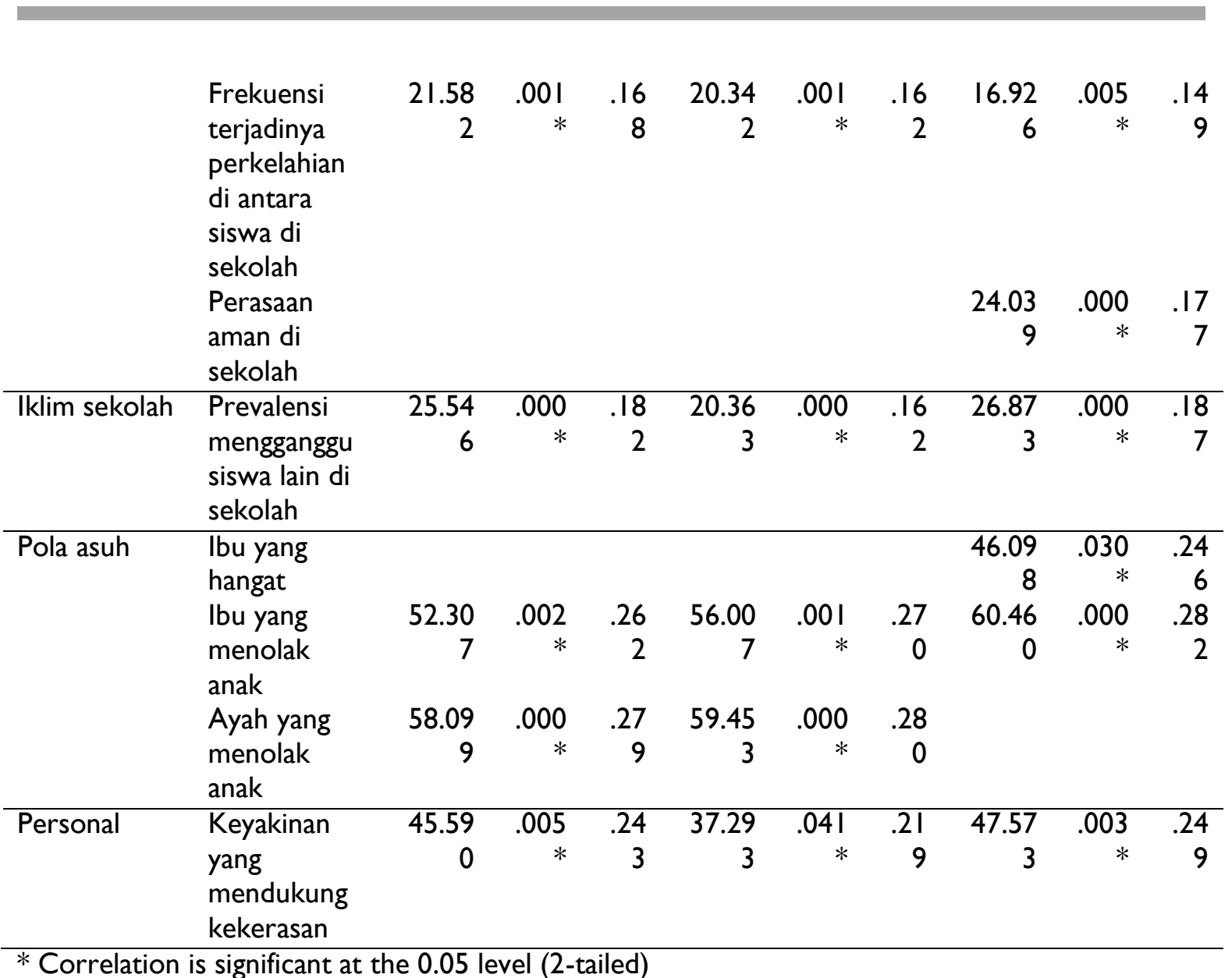

Tabel 2 menjelaskan hasil analisis Chi-square variabel bebas terkait perundungan terhadap ketiga tipe perundungan di sekolah. Hasil analisis yang ditampilkan hanya yang menunjukkan korelasi yang signifikan.

Faktor demografik usia, tidak memiliki korelasi signifikan dengan ketiga tipe perundungan.

Salah satu variabel bebas perundungan di sekolah, yaitu relasi dengan guru yang terdiri dari 3 indikator (guru-guru perhatian terhadap siswa, guru mendengarkan dan memperhatikan pendapat siswa, serta jika memiliki masalah di sekolah, guru akan menolong siswa), ternyata tidak ada satupun yang memiliki korelasi yang signifikan dengan ketiga tipe perundungan.

Dari lima indikator iklim sekolah dari Cornell (2016), hanya indikator prevalensi mengganggu siswa lain di sekolah yang menunjukkan korelasi signifikan dengan ketiga tipe perundungan. Indikator keterikatan siswa terhadap sekolah, penerapan disiplin sekolah, respek terhadap siswa, dan keinginan siswa untuk mencari bantuan, tidak menunjukkan korelasi yang signifikan dengan ketiga tipe perundungan.

Sedangkan untuk pola asuh orang tua, tipe pola asuh (ayah dan ibu) overprotektif dan pola asuh (ayah dan ibu) pencemas, tidak memiliki korelasi signifikan dengan ketiga tipe perundungan. Tipe pola asuh (ayah) yang hangat juga tidak memiliki korelasi signifikan dengan ketiga tipe perundungan. Tetapi pola asuh (ibu) yang hangat memiliki korelasi yang signifikan dengan tipe perundungan psikologis.

Berdasarkan hasil analisis Chi-square tersebut, maka seluruh indikator yang memiliki korelasi signifikan disertakan dalam pengujian regresi logistik binari untuk mengetahui prediktor perundungan sekolah pada siswa SD di Kota Bandung. 


\section{Tabel 3.}

Regresi logistik binari perundungan fisik terhadap variabel demografik, iklim sekolah, pola asuh, dan personal (hanya indikator yang signifikan secara statistik yang ditampilkan)

\begin{tabular}{|c|c|c|c|c|c|c|}
\hline Variabel & Indikator & $\begin{array}{c}\text { B } \\
\text { (Koefisien } \\
\text { regresi) }\end{array}$ & $\begin{array}{l}\text { Wald } \\
\text { statistic }\end{array}$ & $P$ value & OR & $\mathrm{Cl}$ \\
\hline Demografik & $\begin{array}{l}\text { Jenis } \\
\text { kelamin }\end{array}$ & -.439 & 7.281 & .007 & .644 & $.468-887$ \\
\hline $\begin{array}{l}\text { Rasa aman } \\
\text { dan frekuensi } \\
\text { kekerasan di } \\
\text { sekolah }\end{array}$ & $\begin{array}{l}\text { Frekuensi } \\
\text { terjadinya } \\
\text { perkelahian } \\
\text { di sekolahb }^{b}\end{array}$ & .148 & 5.607 & .018 & 1.159 & $\begin{array}{c}1.026- \\
1.310\end{array}$ \\
\hline Iklim sekolah & $\begin{array}{l}\text { Prevalensi } \\
\text { mengganggu } \\
\text { siswa lain di } \\
\text { sekolahc }\end{array}$ & -.142 & 3.864 & .049 & .867 & $.753-1.000$ \\
\hline Pola Asuh & $\begin{array}{l}\text { Ayah yang } \\
\text { menolak } \\
\text { anak }\end{array}$ & .163 & 12.815 & .000 & 1.177 & $\begin{array}{c}1.077- \\
1.288\end{array}$ \\
\hline Personal & $\begin{array}{l}\text { Keyakinan } \\
\text { personal } \\
\text { yang } \\
\text { mendukung } \\
\text { tindak } \\
\text { kekerasan }\end{array}$ & .050 & 7.338 & .007 & 1.051 & $\begin{array}{c}1.014- \\
1.089\end{array}$ \\
\hline
\end{tabular}

aReferensi kategori jenis kelamin: laki-laki

bReferensi kategori frekuensi terjadinya perkelahian di sekolah: setiap hari

cReferensi prevalensi mengganggu siswa lain di sekolah: prevalensi rendah

Nilai rata-rata untuk perundungan fisik adalah $1.63(\mathrm{SD}=.482$, nilai minimum $=1$, nilai maksimum $=2,4.8 \%$ missing value). Sebanyak $63.4 \%(n=770)$ responden berada di atas nilai rata-rata. Korelasi antara beberapa indikator dari variabel prediktor perundungan, tidak menunjukkan signifikansi secara statistik (lihat Tabel 2) sehingga tidak disertakan dalam pengujian regresi logistik binari.

Tabel 3 memperlihatkan hasil uji regresi logistik binari yang menunjukkan bahwa lima indikator berkontribusi untuk menjelaskan skor yang tinggi pada kejadian perundungan fisik di sekolah pada siswa SD di Kota Bandung. Jenis kelamin dan prevalensi mengganggu siswa lain di sekolah menunjukkan kontribusi negatif, sedangkan frekuensi terjadinya perkelahian di sekolah, pola asuh ayah yang menolak anak, serta keyakinan personal yang mendukung tindak kekerasan, menunjukkan kontribusi positif. Koefisien regresi negatif pada indikator jenis kelamin menunjukkan bahwa anak laki-laki memiliki .644 kali lebih besar peluang untuk menjadi korban perundungan fisik dibandingkan anak perempuan. Koefisien regresi negatif pada indikator prevalensi mengganggu siswa lain di sekolah menunjukkan bahwa prevalensi yang rendah memberikan kontribusi sebesar .867 kali atas rendahnya peluang terjadinya perundungan di sekolah.

Pola asuh ayah yang menolak anak memberikan kontribusi paling besar terhadap terjadinya perundungan fisik di sekolah berdasarkan nilai odds ratio. Artinya, siswa yang ditolak oleh ayahnya di rumah, berpeluang lebih besar untuk menjadi korban perundungan fisik di sekolah dengan dipukul oleh siswa lain di sekolah. Frekuensi terjadinya perkelahian di sekolah menunjukkan bahwa semakin sering terjadi perkelahian, maka semakin besar peluang terjadinya perundungan fisik dipukul oleh siswa lain di sekolah. Indikator keyakinan personal yang mendukung tindak kekerasan juga menunjukkan kontribusi positif yang berarti semakin siswa yakin bahwa tindak kekerasan 
adalah cara yang digunakan untuk menyelesaikan masalah, maka semakin besar peluang terjadinya perundungan fisik di sekolah.

Model pengujian regresi logistik binari perundungan fisik ini dapat menjelaskan $66.8 \%$ kasus perundungan fisik (30.1\% terkait kasus di bawah nilai rata-rata dan $87.7 \%$ terkait kasus di atas nilai rata-rata). Model fit tergolong adekuat (Chi-square $=6.550 ; \mathrm{p}<.00 \mathrm{I} ; \mathrm{R}^{2}$ Nagelkerke $\left.=.129\right)$.

\section{Tabel 4.}

Regresi logistik binari perundungan verbal terhadap variabel demografik, iklim sekolah, dan personal (hanya indikator yang signifikan secara statistik yang ditampilkan)

\begin{tabular}{|c|c|c|c|c|c|c|}
\hline Variabel & Indikator & $\begin{array}{c}\text { B } \\
\text { (Koefisien } \\
\text { regresi) }\end{array}$ & $\begin{array}{l}\text { Wald } \\
\text { statistic }\end{array}$ & $P$ value & OR & $\mathrm{Cl}$ \\
\hline Demografik & $\begin{array}{l}\text { Ayah bekerja } \\
\text { di luar } \\
\text { kota/negeri }\end{array}$ & .593 & 10.892 & .001 & 1.809 & $\begin{array}{c}1.272- \\
2.573\end{array}$ \\
\hline Iklim sekolah & $\begin{array}{l}\text { Prevalensi } \\
\text { mengganggu } \\
\text { siswa lain di } \\
\text { sekolaha }^{\mathrm{a}}\end{array}$ & -.159 & 4.153 & .042 & .853 & $.732-.994$ \\
\hline Personal & $\begin{array}{l}\text { Keyakinan } \\
\text { personal } \\
\text { yang } \\
\text { mendukung } \\
\text { tindak } \\
\text { kekerasan }\end{array}$ & .049 & 6.087 & .014 & 1.050 & $\begin{array}{l}1.010- \\
1.092\end{array}$ \\
\hline
\end{tabular}

aReferensi kategori prevalensi mengganggu siswa lain di sekolah: prevalensi rendah

Nilai rata-rata untuk perundungan verbal adalah $\mathrm{I} .7 \mathrm{I}(\mathrm{SD}=.453$, nilai minimum $=\mathrm{I}$, nilai maksimum $=2$, 3.8\% missing value). Sebanyak $71.2 \%(n=778)$ responden berada di atas nilai ratarata. Korelasi antara beberapa indikator dari variable prediktor perundungan, tidak menunjukkan signifikansi secara statistik (lihat Tabel 2) sehingga tidak disertakan dalam pengujian regresi logistik binari.

Tabel 4 memperlihatkan hasil uji regresi logistik binari yang menunjukkan bahwa tiga indikator berkontribusi untuk menjelaskan skor yang tinggi pada kejadian perundungan verbal di sekolah pada siswa SD di Kota Bandung. Indikator prevalensi mengganggu siswa lain di sekolah menunjukkan kontribusi negatif, sedangkan ayah yang tidak tinggal bersama anak karena bekerja di luar kota/luar negeri dan keyakinan personal yang mendukung tindak kekerasan, menunjukkan kontribusi positif bagi peluang terjadinya perundungan verbal di sekolah. Koefisien regresi negatif pada indikator prevalensi mengganggu siswa lain di sekolah menunjukkan bahwa prevalensi yang rendah memberikan kontribusi sebesar .853 kali atas rendahnya peluang terjadinya perundungan di sekolah.

Ayah yang tidak tinggal bersama anak karena bekerja di luar kota/luar negeri memberikan kontribusi paling besar terhadap terjadinya perundungan verbal di sekolah berdasarkan nilai odds ratio. Indikator keyakinan personal yang mendukung tindak kekerasan juga menunjukkan kontribusi positif yang berarti semakin siswa yakin bahwa tindak kekerasan adalah cara yang digunakan untuk menyelesaikan masalah, maka semakin besar peluang terjadinya perundungan verbal dengan memanggil siswa lain dengan nama yang buruk di sekolah. 
Model pengujian regresi logistic binary dapat menjelaskan $72.2 \%$ kasus perundungan fisik $(14.7 \%$ terkait kasus di bawah nilai rata-rata dan $95.1 \%$ terkait kasus di atas nilai rata-rata). Model fit tergolong adekuat (Chi-square $=8.8 \mathrm{I} 8 ; \mathrm{p}<.00 \mathrm{I} ; \mathrm{R}^{2}$ Nagelkerke $\left.=.14 \mathrm{I}\right)$

Tabel 5.

Regresi logistik binari perundungan psikologis terhadap variabel demografik, tingkat kebahagiaan anak di sekolah, relasi dengan teman dan anak lain di sekolah, iklim sekolah, pola asuh, dan personal (hanya indikator yang signifikan secara statistik yang ditampilkan)

\begin{tabular}{|c|c|c|c|c|c|c|}
\hline Variabel & Indikator & $\begin{array}{c}\text { B } \\
\text { (Koefisien regresi) }\end{array}$ & Wald statistic & $P$ value & OR & $\mathrm{Cl}$ \\
\hline Demografik & Jenis kelamin & .519 & 9.537 & .002 & $1.68 \mid$ & $\begin{array}{l}1.209- \\
2.337\end{array}$ \\
\hline $\begin{array}{l}\text { Tingkat } \\
\text { kebahagiaan } \\
\text { anak terkait } \\
\text { kehidupannya } \\
\text { di sekolah }\end{array}$ & $\begin{array}{l}\text { Kebahagiaan } \\
\text { bersama } \\
\text { teman }\end{array}$ & -.107 & 5.146 & .023 & .899 & $.820-.986$ \\
\hline $\begin{array}{l}\text { Relasi dengan } \\
\text { teman dan } \\
\text { anak lain di } \\
\text { sekolah }\end{array}$ & $\begin{array}{l}\text { Teman } \\
\text { biasanya baik }\end{array}$ & -.205 & 5.577 & .018 & 815 & $.688-.966$ \\
\hline Iklim sekolah & $\begin{array}{l}\text { Prevalensi } \\
\text { mengganggu } \\
\text { siswa lain di } \\
\text { sekolahb } \\
\end{array}$ & -.155 & 4.649 & .031 & .856 & $.743-.986$ \\
\hline Pola asuh & $\begin{array}{l}\text { Ibu yang } \\
\text { menolak } \\
\text { anak }\end{array}$ & .076 & 3.290 & .070 & 1.079 & $\begin{array}{l}.994- \\
1.170\end{array}$ \\
\hline Personal & $\begin{array}{l}\text { Keyakinan } \\
\text { yang } \\
\text { mendukung } \\
\text { tindak } \\
\text { kekerasan }\end{array}$ & .071 & 14.526 & .000 & 1.074 & $\begin{array}{l}1.035- \\
1.114\end{array}$ \\
\hline
\end{tabular}

aReferensi jenis kelamin: laki-laki

bReferensi kategori prevalensi mengganggu siswa lain di sekolah: prevalensi rendah

Nilai rata-rata untuk perundungan psikologis adalah I.588 $(\mathrm{SD}=.492$, nilai minimum $=1$, nilai maksimum $=2,5.2 \%$ missing value). Sebanyak $58.8 \%(n=767)$ responden berada di atas nilai ratarata. Korelasi antara beberapa indikator dari variabel prediktor perundungan, tidak menunjukkan signifikansi secara statistik (lihat Tabel 2) sehingga tidak disertakan dalam pengujian regresi logistik binari.

Tabel 5 memperlihatkan hasil uji regresi logistik binari yang menunjukkan bahwa lima indikator berkontribusi untuk menjelaskan skor yang tinggi pada kejadian perundungan psikologis di sekolah pada siswa SD di Kota Bandung. Kebahagiaan bersama teman, relasi dengan teman yang dipersepsi bahwa teman biasanya baik, serta iklim sekolah terkait prevalensi mengganggu siswa lain di sekolah perundungan, menunjukkan kontribusi negatif, sedangkan indikator jenis kelamin, ibu yang menolak anak, dan keyakinan yang mendukung tindak kekerasan menunjukkan kontribusi positif. Siswa yang merasakan kebahagiaan bersama teman dan mempersepsi temannya baik dalam berelasi, memberikan kontribusi atas tidak terjadinya perundungan psikologis pada siswa SD di Kota Bandung. 
Koefisien regresi negatif pada indikator prevalensi mengganggu siswa lain di sekolah menunjukkan bahwa prevalensi yang rendah memberikan kontribusi sebesar .856 kali atas rendahnya peluang terjadinya perundungan di sekolah. Jenis kelamin memberikan kontribusi paling besar terhadap terjadinya perundungan psikologis di sekolah berdasarkan nilai odds ratio.

Koefisien regresi positif pada indikator jenis kelamin menunjukkan bahwa anak perempuan memiliki I.68I kali lebih besar peluang untuk menjadi korban perundungan psikologis dengan dikucilkan oleh anak lain di kelas dibandingkan anak laki-laki. Jenis kelamin memberikan kontribusi paling besar terhadap terjadinya perundungan psikologis di sekolah. Ibu yang menolak anak dan keyakinan personal yang dimiliki siswa yang mendukung tindak kekerasan memberikan kontribusi bagi terjadinya perundungan psikologis pada siswa SD di Kota Bandung.

Model pengujian regresi logistic binary dapat menjelaskan $66.2 \%$ kasus perundungan fisik $(52.5 \%$ terkait kasus di bawah nilai rata-rata dan $76.1 \%$ terkait kasus di atas nilai rata-rata). Model fit tergolong adekuat (Chi-square $=7.991 ; \mathrm{p}<.00 \mathrm{I} ; \mathrm{R}^{2}$ Nagelkerke $=.176$ )

\section{Pembahasan}

Hasil penelitian menunjukkan bahwa keyakinan personal yang mendukung tindak kekerasan memiliki pengaruh positif terhadap ketiga jenis perundungan, yaitu fisik, verbal, dan psikologis. Artinya, siswa yang memiliki keyakinan bahwa mereka boleh melakukan tindakan agresif terhadap orang lain, menggunakan kekerasan sebagai cara untuk menghentikan hal yang tidak disukai serta memiliki keyakinan bahwa mereka akan dianggap pengecut jika menghindar dari perkelahian, akan meningkatkan peluang yang lebih besar untuk terjadinya perundungan di sekolah. Faktor keyakinan personal ini didapatkan oleh anak melalui interaksinya dengan konteks terdekat dalam kehidupannya di dalam microsystem, yaitu melalui keluarga. Keluarga di dalam microsystem adalah konteks yang paling utama dan pertama yang dimiliki oleh anak. Di dalam keluarga, anak pertama kali belajar berinteraksi secara sosial dengan orang tua, orang dewasa lain, dan saudara kandung untuk meningkatkan kemampuan sosial. Jika interaksi di dalam microsystem tidak memfasilitasi kesempatan bagi anak untuk meningkatkan kemampuan sosialnya, anak dapat mengalami kendala dalam berinteraksi dengan konteks lain di dalam sistem yang lebih luas.

Hasil penelitian menunjukkan bahwa peran penting orang tua dalam pengasuhan anak juga menjadi salah satu prediktor perundungan. Pola asuh orang tua yang menolak anaknya merupakan prediktor perundungan fisik dan psikologis. Ayah yang menolak anak memberikan kontribusi sebesar I.I77 kali bagi peluang anak mengalami perundungan fisik di sekolah. Sedangkan ibu yang menolak anak memberikan kontribusi sebesar 1.079 kali bagi peluang anak mengalami perundungan psikologis di sekolah. Orang tua yang menolak anaknya memperlakukan anak dengan tidak adil, menyalahkan anak atas segala sesuatu yang terjadi tidak semestinya, menghukum anak tanpa alasan, mengkritik anak di depan orang lain, tidak memberikan apa yang menjadi kebutuhan anak, serta orang tua menyatakan ketidaksukaan terhadap anak. Dengan penolakan terhadap anak di dalam relasi tatap muka pada konteks keluarga, anak tidak mendapatkan kesempatan untuk meningkatkan kemampuan dirinya karena selalu disalahkan dan ditolak. Anak menjadi bingung dan tidak dapat memahami dirinya sendiri. Anak menjadi mengembangkan gaya pemikiran yang negatif (Gibb, 2002) serta tidak mampu mengembangkan kemandirian dan otonominya (Duncan, 2004). Akibatnya, anak menjadi tidak mampu mengembangkan kemampuan sosial dalam berinteraksi dengan teman sebayanya, sehingga mereka menjadi memiliki risiko ditolak oleh teman sebaya. Akibatnya, mereka mudah untuk dijadikan target perundungan di sekolah. Hal ini sejalan dengan hasil penelitian yang dilakukan oleh Holt, Kantor, dan Finkelhor (2009) yang menunjukkan bahwa anak-anak korban perundungan pada umumnya berasal dari keluarga yang orangtuanya sering mengkritik, tidak memiliki aturan yang jelas, dan tidak memberikan perhatian yang dibutuhkan oleh anak. Penelitian yang dilakukan oleh Espelage dan Hong (2018) juga menunjukkan hasil yang sejalan, di mana orang tua yang keras dan memberikan hukuman mengakibatkan anak mengalami peningkatan peluang menjadi korban perundungan. 
Pola asuh orang tua tidak memberikan kontribusi bagi peluang terjadinya perundungan verbal di sekolah. Namun, ketiadaan ayah di rumah karena bekerja di luar kota/luar negeri memiliki kontribusi paling besar terhadap peluang terjadinya perundungan verbal di sekolah. Siswa yang ayahnya bekerja di luar kota/luar negeri dan tidak hadir setiap hari di rumah, memiliki hampir 2 kali lebih besar peluang menjadi korban perundungan verbal dibandingkan siswa yang ayahnya tidak bekerja jauh di luar kota/luar negeri. Ayah memiliki peran penting dalam pengasuhan anak. Penelitian yang dilakukan oleh Flouri dan Buchanan (2002) menunjukkan bahwa keterlibatan ayah dalam relasinya dengan anak laki-laki dapat mencegah anak mengalami kualitas hidup yang rendah. Keterlibatan ayah memberikan efek buffering yang dapat mencegah anak untuk menjadi korban perundungan. Ayah yang ikut terlibat dalam kehidupan anaknya membuat anak lebih mudah beradaptasi, lebih berhasil di sekolah, dan tidak terlibat pada perilaku antisosial (Hwang \& Lamb, 1997). Kehadiran dan keterlibatan ayah dalam relasinya dengan anak juga membantu meningkatkan kemampuan anak untuk berempati (Lamb, 1987). Di sisi lain, berbagai penelitian menunjukkan bahwa ketidakhadiran ayah merupakan faktor yang berkontribusi pada rendahnya kebahagiaan anak (Flouri \& Buchanan, 2002) dan meningkatkan risiko munculnya masalah perilaku (Dornbusch, Carlsmith, Bushwall, Ritter, Leiderman, Hastorf, \& Gross, 1985). Hasil-hasil penelitian tersebut sejalan dengan temuan dalam penelitian ini yang menunjukkan bahwa ketidakhadiran ayah meningkatkan peluang anak menjadi korban perundungan.

Beberapa penelitian menunjukkan bahwa keterlibatan ayah memberikan efek yang berbeda dalam perkembangan pada anak laki-laki dan anak perempuan (Williams \& Radin, 1999) dan memberikan pengaruh yang besar pada anak laki-laki daripada pada anak perempuan (Cabrera, Tamis-LeMonda, Bradley, Hifferth, \& Lamb, 2000). Keterlibatan ayah dalam interaksinya dengan anak laki-laki dapat mencegah anak mengalami kualitas hidup yang rendah (Flouri \& Buchanan, 2002). Walaupun dalam penelitian ini tidak dilakukan pengujian mengenai efek jenis kelamin dan kehadiran ayah terhadap peluang terjadinya perundungan, namun hasil temuan dari penelitian-penelitian terdahulu (Williams \& Radin, 1999; Cabrera et al., 2000; Flouri \& Buchanan, 2002) menjadi topik yang menarik untuk dikaji lebih lanjut dalam penelitian berikutnya untuk menguji apakah ayah yang menolak anak lakilaki memberikan kontribusi bagi peluang anak laki-laki mengalami perundungan fisik di sekolah, dan apakah ibu yang menolak anak perempuan memberikan kontribusi bagi peluang anak perempuan mengalami perundungan psikologis di sekolah.

Salah satu variabel iklim sekolah, yaitu prevalensi mengganggu siswa lain di sekolah memiliki pengaruh negatif terhadap ketiga jenis perundungan. Artinya, prevalensi yang rendah memberikan kontribusi bagi semakin jarangnya terjadi perundungan di sekolah. Jika sesama siswa di sekolah sering saling mengganggu ataupun mengejek, maka peluang terjadinya perundungan akan semakin besar, baik perundungan fisik, verbal, maupun psikologis. Hal ini terjadi pada salah satu kasus yang viral di Kota Bandung, di mana perundungan terjadi karena pada awalnya siswa saling ejek (Yulius, 2018). Berdasarkan hal ini, tampaknya guru perlu memberikan perhatian khusus jika di sekolah sering terjadi siswa yang saling mengganggu dan mengejek, walaupun belum dalam bentuk perilaku agresif (belum menunjukkan terjadinya perundungan). Karena, prevalensi menggangu siswa lain dapat meningkatkan kontribusi bagi terjadinya perundungan yang bersifat agresif.

Faktor demografik jenis kelamin menjadi prediktor perundungan fisik dan psikologis, tetapi bukan merupakan prediktor perundungan verbal. Siswa laki-laki memiliki lebih besar peluang menjadi korban perundungan fisik, sedangkan siswa perempuan memiliki lebih besar peluang menjadi korban perundungan psikologis dibandingkan siswa laki-laki. Hal ini sejalan dengan hasil temuan yang menunjukkan bahwa anak laki-laki cenderung terlibat pada perilaku agresif (Bjorkqvist, Lagerspetz, \& Kaukianinen, 1992; Crick \& Grotpeter, 1995), sedangkan anak perempuan lebih sering terlibat pada perundungan yang terkait pengucilan anak lain dalam relasi sosial (Crick \& Grotpeter, 1995). Anak laki-laki lebih sering terlibat dalam perundungan fisik karena mereka lebih sering didorong untuk menampilkan perilaku yang lebih bersifat fisikal dalam relasinya di lingkungan. Secara kultural, dalam interaksi di microsystem di rumah dan di sekolah, anak laki-laki akan dianggap cengeng dan pengecut jika tidak berani menampilkan tingkah laku agresif. Sebaliknya, mereka akan dianggap lebih maskulin jika menampilkan perilaku yang lebih agresif secara fisik. Hal 
ini juga tampak dalam interaksi antara anak dengan orang tua maupun anak dengan saudara kandungnya.

Di sekolah, mereka juga akan dipandang pengecut oleh teman sebayanya jika tidak menampilkan perilaku agresif secara fisik. Hal ini sejalan dengan hasil temuan Rivers dan Smith (1994) yang menunjukkan bahwa anak laki-laki lebih didorong untuk bertingkah laku lebih agresif secara fisik, seperti memukul ataupun menendang. Hal inilah yang perlu mendapatkan perhatian serius untuk menghindari terjadinya perundungan fisik pada anak laki-laki. Mereka perlu diajarkan bahwa menjadi maskulin bukan berarti menampilkan perilaku agresif secara fisik, tetapi mampu menampilkan perilaku baik dan bertanggung jawab tanpa menunjukkan kekerasan.

Faktor demografik jenis kelamin merupakan prediktor yang memiliki kontribusi paling besar atas terjadinya perundungan psikologis di sekolah. Hasil menunjukkan bahwa siswa perempuan sangat rentan menjadi korban perundungan psikologis dengan dikucilkan oleh anak-anak lain di kelas, di mana peluangnya hampir mencapai 2 kali peluang siswa laki-laki dalam mengalami perundungan psikologis. Hasil penelitian ini sejalan dengan beberapa penelitian lain yang menunjukkan bahwa siswa laki-laki lebih sering menjadi korban perundungan fisik (Griffiths, Wolke, Page, Horwood, \& the ALSPAC Study Team, 2006; Wang, lanotti, \& Nansel, 2009). Hal ini terjadi karena laki-laki lebih sering terlibat dalam berbagai bentuk agresi (Crick \& Grotpeter, 1995; Neal, 2007), sedangkan perempuan lebih sering terlibat pada pengucilan secara sosial (Crick \& Grotpeter, 1995).

Pada perundungan fisik, frekuensi terjadinya perkelahian di sekolah memberikan kontribusi bagi terjadinya perundungan di sekolah. Semakin sering terjadi perkelahian di sekolah, maka semakin peluang terjadinya perundungan di sekolah meningkat I, I5 kali lebih sering.

Dari ketiga tipe perundungan, hanya pada perundungan psikologis muncul prediktor yang terkait relasi dengan teman di sekolah. Siswa yang merasakan kebahagiaan dalam relasinya dengan teman di sekolah serta siswa yang menghayati bahwa pada umumnya teman-teman baik terhadap mereka, memiliki peluang yang lebih besar untuk tidak mengalami perundungan psikologis. Artinya, dengan memiliki teman yang baik dan mendapatkan kepuasan dalam relasi pertemanannya di dalam microsystem pada konteks sekolah, siswa tidak akan dikucilkan di kelas. Pertemanan merupakan faktor kritis yang dapat mengurangi resiko siswa menjadi korban perundungan. Berbagai penelitian menunjukkan bahwa teman memiliki peran penting dalam menurunkan angka kejadian perundungan (Bollmer, Milich, Harris, \& Maras, 2005; Boulton, Trueman, Chau, Whitehand, \& Amatya, 1999; Hodges, Boivin, Vitaro, \& Bukowski, 1999). Penelitian yang dilakukan oleh Hodges et al. (1999) menunjukkan bahwa peluang menjadi korban perundungan dilemahkan oleh persahabatan yang protektif. Sedangkan anak-anak yang ditolak oleh anak-anak sebayanya akan menjadi target yang mudah untuk dijadikan korban perundungan (Card \& Hodges, 2008).

Kondisi ini menjelaskan bahwa relasi di dalam microsystem, baik dalam konteks keluarga maupun dalam konteks sekolah, menjadi dasar penting bagi anak untuk dapat menjalin relasi yang harmonis dengan orang tua dan anak-anak lain di sekolah, sehingga dapat mencegah terjadinya perundungan di sekolah.

\section{Kesimpulan}

Tingginya angka kejadian perundungan pada siswa SD di Kota Bandung merupakan persoalan serius yang patut mendapatkan perhatian dan upaya penanganan. Terdapat sejumlah prediktor perundungan siswa SD di Kota Bandung. Keyakinan personal yang mendukung tindak kekerasan merupakan salah satu prediktor yang memberikan kontribusi bagi terjadinya ketiga tipe perundungan pada siswa SD di Kota Bandung, yaitu fisik, verbal, dan psikologis.

Pola asuh ayah yang menolak anak memberikan kontribusi paling besar bagi terjadinya perundungan fisik. Ayah yang tidak hadir setiap hari di rumah karena bekerja di luar kota/luar negeri memberikan kontribusi paling besar bagi terjadinya perundungan verbal. Sedangkan jenis 
kelamin memberikan kontribusi paling besar bagi peluang terjadinya perundungan psikologis, di mana anak perempuan memiliki peluang lebih besar menjadi korban perundungan psikologis dibandingkan anak laki-laki.

Mengacu pada teori sosial-ekologi dari Bronfenbrenner (1979), penanganan kasus perundungan ini perlu dilakukan secara sistemik dimulai dari lapisan sistem yang paling dasar dan dekat dengan anak, yaitu microsystem. Hasil penelitian menunjukkan bahwa faktor-faktor yang menjadi prediktor perundungan adalah faktor-faktor yang terkait relasi tatap muka antara anak dengan orang tuanya di rumah. Dengan demikian, orang tua perlu memperbaiki cara pengasuhan terhadap anak yang lebih berorientasi pada penanaman nilai-nilai kebaikan dan memberikan perhatian yang dibutuhkan oleh anak di rumah. Orang tua perlu memperbaiki cara pengasuhan yang lebih afektif, tidak menolak anak, dan menampilkan nilai yang mendukung perilaku prososial.

Bagi guru di sekolah, perlu memperhatikan prevalensi terjadinya tindakan saling mengganggu atau mengejek di antara siswa walaupun belum merupakan tindakan agresif. Karena semakin sering terjadi tindakan saling mengganggu dan saling ejek di antara siswa, yang walaupun pada awalnya dimaksudkan untuk bercanda, pada akhirnya akan meningkatkan peluang terjadinya perundungan di sekolah, baik perundungan fisik, verbal, dan psikologis. Guru perlu membangun iklim yang kondusif di kelas agar siswa dapat membangun pertemanan yang baik dengan siswa lain di kelas dan merasakan kebahagiaan bersama teman-temannya, karena kedua hal terkait relasi dengan teman di sekolah ini, berkontribusi bagi rendahnya kejadian perundungan di sekolah.

Penjelasan sosial-ekologi mengenai perundungan menunjukkan bahwa siswa yang terlibat dalam perundungan sebagai korban dan pelaku, adalah sebagai hasil interaksi yang kompleks antara karakteristik pribadi individu dengan keluarga, sekolah, teman sebaya, dan lingkungannya. Karenanya, dengan menyasar tingkatan berjenjang pada sosial ekologi diharapkan dapat meningkatkan iklim sosial di mana anak dapat menghabiskan waktu dan mengurangi perundungan dengan cara memperkuat aspek protektif pada sistem.

\section{Acknowledgment}

Penelitian ini dibiayai melalui data Penelitian Dosen Utama LPPM Universitas Islam Bandung. Terimakasih kepada Andita, Annisa, Dinni, Hana, Restu, dan Virna yang telah membantu dalam proses pengambilan data di lapangan.

\section{REFERENSI}

Bjorkqvist, K., Lagerspetz, K.M., \& Kaukianinen, A. (1992). Do girls manipulate and boys fight? Developmental trends in regard to direct and indirect aggression. Aggressive Behavior, 18(2), I 17-I27. doi:I0.1002/I098-2337(1992) |8:2<I I7::AID-AB2480 I80205>3.0.CO;2-3

Bollmer, J. M., Milich, R., Harris, M. J., \& Maras, M. A. (2005). A friend in need: The role of friendship quality as a protective factor in peer victimization and bullying. Journal of Interpersonal Violence, 20(6), 70I-7 I2. doi:I0.I I77/0886260504272897

Boulton, M. J., Trueman, M., Chau, C., Whitehand, C., \& Amatya, K. (1999). Concurrent and longitudinal links between friendship and peer victimization: Implications for befriending interventions. Journal of Adolescence, 22(4), 46I-466. doi:10.1006/jado. 1999.0240

Borualogo, I.S., \& Casas, F. (2019a). Adaptation and validation of The Children's Worlds Subjective Well-Being Scale (CW-SWBS) in Indonesia. Jurnal Psikologi, 46(2), 102-I I6. Doi: I0.22I46/jpsi.38995.

Borualogo, I.S., \& Casas, F. (2019b). Subjective well-being of bullied children in Indonesia. Applied Research in Quality of Life. Doi: 10.1007/s I 482-019-09778-I.

Borualogo, I.S. \& Gumilang, E. (2019). Kasus perundungan anak di Jawa Barat: Temuan awal Children's Worlds Survey di Indonesia. Psympathic, 6(I), I5-30. Doi:I0.I5575/psy.v6il.4439 
Borualogo, I. S., Gumilang, E., Mubarak, A., Khasanah, A., Wardati, M. A., Diantina, F. P., Permataputri, I., \& Casas, F. (2018). Process of translation of the Children"s Worlds Subjective Well-Being Scale in Indonesia. Social and Humaniora Research Symposium, 307, 180- |83. Retrieved from https://www.atlantis-press.com/proceedings/sores-18/559|53 I2

Bronfenbrenner, U. (1979). The ecology of human development: Experiments by nature and design. USA : Harvard University Press

Cabrera, N.J., Tamis-LeMonda, C.S., Bradley, R.H., Hofferth, S., \& Lamb, M.E. (2000). Fatherhood in the twenty-frist century. Child Development, 7 I (I), I27-I36. doi:I0.I I I I/I467-8624.00I 26

Card, N.A., \& Hodges, E.V.E. (2008). Peer victimization among school children: Correlations, causes, consequences, and considerations in assessment and intervention. School Psychology Quarterly, 23(4), 45I-46I. doi:I0.1037/a00I2769

Cook, C. R., Williams, K. R., Guerra, N. G., Kim, T. E., \& Sadek, S. (2010). Predictors of bullying and victimization in childhood and adolescence: A meta-analytic investigation. School Psychology Quarterly, 25(2), 65-83. doi:10.1037/a0020149

Copeland, W. E., Wolke, D., Angold, A., \& Costello, E. J. (2013). Adult psychiatric outcomes of bullying and being bullies by peers in childhood and adolescence. JAMA Psychiatry, 70(4), 419-426. doi:10.100I/jamapsychiatry.2013.504

Cornell, D. (2016). School Climate Bullying Survey. Retrieved from http://curry.virginia.edu/uploads/resourceLibrary/Authoritative_School_Climate_Survey_Re search_Summary_January_2016.pdf

Crick, N.R., \& Grotpeter, J.K. (1995). Relational aggression, gender, and social-psychological adjustment. Child Development, 66(3), 7I0-722. doi:I0.I I I I/j.I467-8624.1995.tb00900.x

Dombrowski, S. C., \& Gischlar, K. L. (2006). Supporting school professionals through the establishment of a school district policy on child maltreatment. Education, I27(2), 234-243.

Dornbusch, S., Carlsmith, J.M., Bushwall, S.J., Ritter P.L., Leiderman, H., Hastorf, A.H., \& Gross, R.T. (1985). Single parents, extended households, and the control of adolescents. Children Development, 56(2),326-34I. doi: 10.2307/I I 29723

Duncan, R.D. (2004). The impact of family relationships on school bullies and victims. In D.L. Espelage \& S.M. Swearer (Eds.), Bullying in American schools: A social-ecological perspective on prevention and intervention (pp. 227-244). Mahwah, NJ: Erlbaum.

Espelage, D.L., \& Hong, J.S. (2018). Children who bully or are bullied. In T.H. Ollendick (Eds.), The Oxford Handbook of Clinical Child and Adolescent Psychology. (pp. I-28). The UK : Oxford University Press.

Espelage, D.L., Low, S., \& De La Rue, L. (20I2). Relations between peer victimization subtypes, family violence, and psychological outcomes during adolescence. Psychology of Violence, 2(4), 313-324. doi:10.1037/a0027386

Espelage, D.L., \& Swearer, S.M. (2003). Research on school bullying and victimization: What have we learned and where do we go from here?. School Psychology Review, 32(3), 365-383.

Espelage, D. L., Bosworth, K., \& Simon, T. R. (2000). Examining the social context of bullying behaviors in early adolescence. Journal of Counseling \& Development, 78(3), 326-333. doi:10.1002/j.1556-6676.2000.tb019|4.x

Flouri, E., \& Buchanan, A. (2002). Life satisfaction in teenage boys: the moderating role of father involvement and bullying. Aggressive Behavior, 28(2), I26-I33. doi:I0.1002/ab.900 I4

Gibb, B. E. (2002). Childhood maltreatment and negative cognitive styles: A quantitative and qualitative review. Clinical Psychology Review, 22(2), 223-246. doi:10.1016/502727358(0I)00088-5 
Griffiths, L.J., Wolke, D., Page, A.S., Horwood, J.P. \& the ALSPAC Study System. (2006). Obesity and bullying: different effects for boys and girls. Archives of Disease in Childhood, 9I(2), I2I|25. doi:10.1|36/adc.2005.0723 |4

Hodges, E.V.E., Boivin, M., Vitaro, F., \& Bukowski, W.M. (1999). The power of friendship: Protection against an escalating cycle of peer victimization. Developmental Psychology, 35(I), 94-I0I. doi:10.1037/00I2-1649.35.1.94

Holt, M.K., Kantor, G.K., \& Finkelhor, D. (2009). Parent/child concordance about bullying involvement and family characteristics related to bullying and peer victimization. Journal of School Violence, 8(I), 42-63. doi:I0.1080/I53882208020678I3

Hwang, C.P., \& Lamb, M.E. (1997). Father involvement in Sweden: a longitudinal study of its stability and correlates. International Journal of Behavioral Development, 2I(3), 62I-632. doi: I0.1080\%2F0I65025973848II

Ispranoto, T. (2018, September 5). Bocah bandung korban bully ternyata dianiaya sejak kelas 4 SD. DetikNews. Retrieved from https:/news.detik.com/berita-jawa-barat/d-4199065/bocahbandung-korban-bully-ternyata-dianiaya-sejak-kelas-4-sd

Kaminski, J.W., \& Fang, X. (2009). Victimization by peers and adolescent suicide in three US samples. Journal of Pediatrics, 155(5), 638-688. Doi:10.1016/j.jpeds.2009.04.06I

Kim, Y. S., Koh, Y., \& Leventhal, B. (2005). School bullying and suicidal risk in Korean middle school students. Pediatrics, II (2), 357-363. doi:10.1542/peds.2004-0902

Kim, Y.S., \& Leventhal, B. (2008). Bullying and suicide: A review. International Journal of Adolescent Medicine and Health, 20(2), I33-I54. doi:I0.15 I5/IJAMH.2008.20.2.133

Lamb, M.E. (1987). Introduction: the emergent American father. In: M.E. Lamb (Eds.), The fathers' role: crosscultural perspectives (pp. 3-26). Hillsdale, NJ: Lawrence Erlbaum Associates.

Muris, P., Meesters, C., \& van Brakel, A. (2003). Assessment of anxious rearing behaviors with a modified version of Egna Minnen Beträffande Uppfostran Questionnaire for Children. Journal of Psychopathology and Behavioral Assessment, 25(4), 229-237. doi: 10.1023/A:1025894928I31

Musu-Gillette, L., Zhang, A., Wang, K., Zhang, J., Kemp, J., Diliberti, M., \& Oudekerk, B.A. (2018). Indicators of School Crime and Safety: 2017 (NCES 2018-036/NCJ 25/4/3). National Center for Education Statistics, U.S. Department of Education, and Bureau of Justice Statistics, Office of Justice Programs, U.S. Department of Justice. Washington, DC

Neal, J.W. (2007). Why social networks matter: A structural approach to the study of relational forms of aggression in middle childhood and adolescence. Child and Youth Care Forum, 36(56), | 95-2 I I. doi: I0.1007/s I0566-007-9042-2

Olweus, D. (1978). Aggression in the schools: bullies and whipping boys. Washington, D.C.: Hemisphere Press (John Wiley).

Rivers, I., \& Smith, P.K. (1994). Types of bullying behaviour and their correlates. Aggressive Behavior, 20(5), 359-368. doi:10.1002/1098-2337(1994)20:5\%3C359::AIDAB2480200503\%3E3.0.CO;2-J

Ttofi, M. M., Farrington, D. P., Losel, F., \& Loeber, R. (20I I). Do the victims of school bullies tend to become depressed later in life? A systematic review and meta-analysis of longitudinal studies. Journal of Aggression, Conflict, and Peace Research, 3(2), 63-73. doi: I0.I I08/I759659IIIII 32873

United Nations (2016). Ending the torment: tackling bullying from the schoolyard to cyberspace. United Nations Special Representative of the Secretary General on Violence Against Children. Retrieved from 
https://www.researchgate.net/profile/Ha_Le43/publication/309193756_Bullying_and_Educati onal_Stress in Schools in East_Asia/links/

Van de Vijver, F.J.R. (20I5). Methodological aspects of cross-cultural research. In M. Gelfand, Y. Hong, \& C.Y. Chiu (Eds.), Handbook of advances in culture \& psychology (Vol. 5, pp.I0I-160). New York, NY:Oxford University Press

Van de Vijver, F.J.R., Hambleton, R.K. (1996) Translating Tests: Some Practical Guidelines. European Psychologist, I (2), 88-99. doi:I0.1027/1016-9040.1.2.89

Van de Vijver, F.J.R., \& Poortinga, Ype. (2005) Conceptual and Methodological Issues in Adapting Test. Retrieved from www.researchgate.net/publication/235660908_

Wang, J., lannotti, R.J., \& Nansel, T.R. (2009). School Bullying Among Adolescents in the United States : Physical, Verbal, Relational, and Cyber. Journal of Adolescent Health. 45(4), 368-375. doi:10.1016/j.jadohealth.2009.03.021

Williams, E., \& Radin, N. (1999). Effect of father participation in child rearing: twenty-year followup. American Journal of Orthopsychiatry, 69(3), 328-336. doi:10.1037/h0080407

Wolke, D., Woods, S., Bloomfield, L., \& Karstadt, L. (2000). The association between direct and relational bullying and behaviour problems among primary school children. Journal of Child Psychology, 4 I (8), 989-I002. doi: I0.1 I I I/I469-7610.00687

Yulius, Y. (2018, September 3). 6 fakta soal aksi bullying di SDN 023 Pajagalan Kota Bandung berawal dari aksi jahil. Jabar Tribun News. Retrieved from Jabar.tribunnews.com//20/8/09/03/6-fakta-soal-aksi-bullying-di-sdn-023-pajagalan-kotabandung-berawal-dari-aksi-jahil 